\title{
A Community of Many Worlds: Arab Americans in New York City
}

Kathleen Benson and Philip M. Kayal, eds.

New York: The Museum of the City of New York, 2002. 280 pages.

This edited collection complemented a March 2001 museum exhibit and is based upon a February 2000 Columbia University conference and a threeyear Ford Foundation-sponsored research project. It provides a general overview of the history and diversity of Arab Americans in New York City and is particularly strong in the area of the arts, featuring several chapters on literature and music, including several first-person narratives. This two-part book, which surveys both the historical and the contemporary scenes, is further enhanced by forty black-and-white photographs, including thirteen by Empire State College's Mel Rosenthal.

New York contains the third largest Arab-American community, after Dearborn (Michigan) and Los Angeles. In the first chapter, Alixa Naff explains that the community was formed around 1895, when Christian mis- 
sionaries in Syria encouraged Arab Christians near Mount Lebanon to work in New York for a couple of years to make money for their families. Syrian and Lebanese immigrants initially gathered at Washington Street in Lower Manhattan and soon moved to Atlantic Avenue in the South Ferry portion of Brooklyn. From 1899-1910, 56,909 Syrian immigrants arrived in New York.

In the book's first part, two historical chapters are followed by entries on literature, music, photography, and first-person accounts. Philip Kayal points out that Arab-American is a cultural and ethnic - but not a religious - category, for most Arab Americans are Christian, not Muslim. Jonathan Friedlander reveals that the first Arab-American immigrant, Antonio Bishallany, visited from Lebanon in 1854 to gather evangelical teachings for use back home. This four-page and six-photograph entry on representations in historical archives could be expanded into a larger work.

The book's second part begins with Yvonne Haddad's survey of contemporary demographics, organizations, and political issues. According to Haddad, there are 2 million Arab Christians and 1 million Arab Muslims nationwide. The Columbia Ford Project estimates that of the 600,000 Muslims living in New York, only 40,800-74,400 are Arab. From one-third to one-half of New York's Arab Americans are Muslim.

The editors successfully show the diversity within the category of Arab American. For example, Walter Zenner introduces the transplantation of Aleppo's (Syria) Sephardic Jewish community to Flatbush, Brooklyn, and quotes population estimates of 40,000 Syrian Jews in New York. The 1990 census figures were lower, Zenner points out: 11,610 Arab Jews made up 23 percent of the total Arab population.

The Columbia Ford Project's finding on the rate of mosque growth is similar to the University of California - Santa Barbara Ford Project that I helped coordinate. Louis Abdellatif Cristillo and Lorraine C. Minnite report an increase from six mosques in the late 1970s to 100 in June 1999. Jerrilynn Dodds provides a snapshot of her excellent book New York Masjid (Power House Books: 2002). She points out that only six of the 100 New York mosques are purpose-built structures. In addition, she mentions the contradiction that mosque architecture is theologically irrelevant, since its primary goal is to facilitate focused prayer. However, the buildings are negotiated markers of identity nonetheless.

Paula Hajar contributes an interesting chapter on education by contrasting two different primary schools' approaches to the inclusion of ArabAmerican children. Of the 25 teachers she surveyed, she labels 8 as "tolerators," or what I would call passive assimilationists; 12 as “critics,” or active 
assimilationists; and 5 as "embracers," also known as multiculturalists, accommodationists, or pluralists.

In chapter 15, Jack Shaheen summarizes his book Reel Bad Arabs: How Hollywood Vilifies a People (Interlink Publishing Group: 2001). An interesting detail is how the Council on American-Islamic Relations (CAIR) convinced Paramount to remove Muslim terrorists from its 2001 film "The Sum of All Fears” and replace them with neo-Nazis. According to Abdeen Jabara in chapter 17, 10 percent of the victims on the Titanic were Syrian immigrants. The book concludes with a prosaic comment by conference attendee Tala Manassah, who remarks that when people ask her "What are you?" she has been tempted to respond, "a New Yorker, a vegetarian, a fan of Fairouz, a Palestinian-American," depending on the context or her mood at the time.

This book is most useful for readers interested in the origins of Arab immigration, the community's diversity, and the range of issues facing an ethnic minority living in the United States. As an edited collection, it does not provide a systematic analysis but does offer useful insights, especially in literature and the arts. For example, several chapters mention Kahlil Gibran (1883-1931). The book could have said more about the relationships between Arab Jews, Christians, and Muslims, as these groups are addressed individually, but never comparatively. Overall, however, the book provides a welcome contribution to the history and diversity of Arab Americans. Individual chapters could become assigned reading in college courses on issues of immigration, ethnicity, and minority literatures in the United States.

Vincent F. Biondo III Visiting Faculty, Department of Religion Florida State University, Tallahassee, FL 